\title{
Amanda Krzyworzeka
}

\section{Changes in Farmers' Modes of Work in Podlasie*}

\begin{abstract}
Over a long time, a unique peasant mode of work developed in rural areas, which has been described in substantial detail by scholars including ethnographers, historians and rural sociologists. It was largely based on concentrating on the process and not the result, affirming work as such, cooperation with family members and neighbours, and work being embedded in a social context. This model underwent substantial change already under communism, but recent decades have accelerated the process. In the face of the structural transformation of rural areas, but also wider changes related to the sphere of work in late modernity, values once fundamental to peasants no longer play such an important role in the lives of present-day farmers. They have been replaced with other attitudes; different skills have become necessary, different attitudes have become valuable. The reasons for this include the fact that farmers realise that their children will probably seek their life's path outside agriculture, and therefore they bring them up differently. The paper discusses not only new modes of work in agriculture and the system of values behind them, but also the sources from which farmers draw such new models.
\end{abstract}

Keywords: ethnography, farmers' modes of work, agricultural work, deagrarianisation, Poland.

\section{Introduction}

Centuries of working on the land resulted in a unique mode of farmers' work that we could observe in late 20th century, and which recently underwent significant changes with the extremely rapidly changing conditions in agriculture. Some researchers believe it is possible to trace the influence of earlier circumstances in subsequent modes of work; for example, attitudes that developed under serfdom continued to affect the way peasants worked and the values they professed for a long time afterwards (cf.

\footnotetext{
Amanda Krzyworzeka, PhD, Assistant Professor, Institute of Ethnology and Cultural Anthropology, University of Warsaw, 4 Żurawia St., 00-503 Warsaw, Poland, e-mail: a.krzyworzeka@uw.edu.pl, ORCID: 0000-0003-4245-5030.

${ }^{*}$ The paper is based on ethnographic fieldwork carried out under National Science Centre (NCN) grant no. 2013/09/B/HS3/04302.
} 
Dobrowolski and Woźniak 1976). Sources of certain types of behaviour might also be sought in folk religiousness, the social relations between the peasants and other classes, including the landed gentry and intelligentsia, and, finally, in the unique role that was officially ascribed to farmers under communism (in People's Poland).

Farming has been always changing, adapting to current circumstances (Dobrowolski and Woźniak 1976; Harris 2005); sometimes those transformations were rather smooth and slow, while in other times they were rapid and drastic (e.g. after the World War II). However, there were never very sharp boundaries; some elements of previous customs, values and modes of operation remain for a long time and can be traced back to the past. That is why in this article I show the older sources of farmers' modes of work, as they are still relevant for understanding some modern phenomena.

Today we are dealing with an extraordinarily dynamic period of changes in the modes of work in rural areas, which began with the collapse of People's Poland and the shift to a market economy. Further changes followed almost 15 years later, with Poland's accession to the European Union. The last 15 years, i.e. the time when Poland has been subject to the EU's common agricultural policy (CAP), have brought Polish farmers many structural changes, which have resulted, among other things, in the depopulation of rural areas, an increase in the average farm size, and new requirements related to the quality of food produced.

Economic, legal, technological and social changes have had a significant impact on farmer attitudes as well as work strategies and modes. The paper will discuss the changes in farmers' modes of work from the point of view of anthropology (particularly economic anthropology and the anthropology of work), ${ }^{1}$ starting with a presentation of the traditional model of working on the land. This will be followed by the contemporary, very different mode of work pursued by those farmers who have adjusted their farms to EU requirements and have been successful in staying on the market. Alongside the literature on the subject, the conclusions related to recent decades will also be based on the author's own, long ethnographic fieldwork conducted among farmers in the Podlasie, Roztocze, Mazovia and Podhale regions ${ }^{2}$ over the past 20 years.

1 Wilk and Cliggett 2009; Applebaum 1992; for the review of Polish tradition in anthropology of work see Krzyworzeka 2019.

2 The Podlasie and Mazovia projects in particular focused on issues of the work of farmers; they were carried out in the years 2004-2008 (Podlasie), 2015-2018 (Podlasie), and 2015-2019 (Mazovia). Among other publications, their effects can be found in Krzyworzeka 2014, 2017 and 2018. In accordance with the methodology of ethnographic fieldwork, I spent weeks or months living in the gmina/commune units involved in the studies, conducting participant observation, in-depth ethnographic interviews and casual conversations with residents. 


\section{What Moulded Farmers' Modes of Work?}

A farmer's workplace is where his home is. This trivial observation has farreaching consequences: if you work where you live, it is hard to strictly set working time apart; it is often impossible to mark the boundary between activities that are part of work (e.g. repairing the paving around the cowshed) and those belonging to family life (e.g. repairing the paving around the house).

To some extent, the fusion of workplace and home also determines the family character of farming, which still predominates in Poland. Wherever the household and the farm are one, professional life largely overlaps with family life: not only do work issues permeate easily into family life (dinnertime discussions on farmingrelated plans), but often all the family members work or help on the farm. However, the farm relies on family members' labour not only because they live in one household or are emotionally committed. It is often a necessity, because it is very hard to find outside workers/helpers on the market, and even with the extent of mechanisation today, in many cases a farmer would be unable to run the farm single-handed; extra hands are needed.

Another unique feature of agriculture with a definite impact on farmers' modes of work, both in the past and today, is dependence on external factors. Of course, external factors like market fluctuations, the weather, consumer trends etc. have to be taken into consideration in any occupation, but dependence on nature is greater in agriculture than in other sectors. A few weeks of drought can obliterate months of work, while the African swine fever (ASF) outbreak can destroy all a farmer owns and leave him with multi-million loans and no resources to repay them.

In her already classic study on the changing model of work among the rural population, Anna Zadrożyńska wrote about the self-evident character of work in the countryside (1983, p. 13 et seq.). This was not a voluntary sphere subject to reflection. According to her, work in the traditional culture model was:

activity of great social, economic, psychological, worldview significance [...] it organised daily life [...] it did not have to have standardised time assigned to the performance of particular actions, which were carried out throughout the day with varying intensity [...] it was supplemented with recreation and fun which, however, were not a part of free time but were necessary activities complementing work ${ }^{3}[\ldots]$ so free time did not exist [...]

3 This was the case with tłoka, a traditional form of mutual help in which neighbours would gather at one of their farms and spend the day working in the field there, after which they feasted together, moving on to another neighbour's farm the next day and repeating the cycle. Tłoka was a frequently used form of help for jobs requiring a greater number of people, and was especially popular in eastern Poland (cf. Zawistowicz-Adamska 1951, 1976). 
all time outside work was qualitatively its opposite, it was a time of non-work [...] non-work time as a value was equivalent to work time, enabling both work and non-work to be acknowledged as values [...] the notion of non-work contained elements of fun, rest, recreation, made use of content stemming from work in a way reminiscent of a game or a competition (Zadrożyńska 1983, pp. 19-20).

It is worth noting that Zadrożyńska considers non-work as the key category, enabling work to be balanced, set apart and given shape. In a sense, it is a necessary condition of the existence of a balanced work sphere (Krzyworzeka 2019). A reference to the supernatural sphere also appears here: work was part of the cosmological vision of the world, it arose from it, and it was this religious aspect that gave work meaning and its very important place in farmers' lives. Hence peasants' attitude towards the land, as described extensively in the literature (e.g. Buchowski 2006; Bukraba-Rylska 2012; Bystroń 1947; Cancian 1989; Chałasiński 1938; Halamska 2000; Wolf 1957), could not be reduced to purely economic or rational calculations and was characterised by a sense of duty and responsibility.

Another characteristic feature of the rural population in olden times was an attachment to tradition, as described extensively by Kazimierz Dobrowolski and Andrzej Woźniak (1976; cf. Zadrożyńska 1983, p. 16). Of course, we are not speaking about an objective tradition or the inflexible repetition of patterns inherited from parents and grandparents, but about the conviction that these patterns must be repeated, and the importance given to them. Thus, regardless of the changes actually taking place, peasants believed they were performing most work in the same way their ancestors had, and invoking the past in itself was often sufficient legitimisation of the activities they undertook.

The economic aspect of agricultural work was also unique, as William Thomas and Florian Znaniecki described so well:

One of the reasons why the relation between work and wages is not taken into account is certainly the attitude of the Polish peasant toward work. While among handworkers a long tradition [...] attracted the attention to the results of the work, the peasant is fundamentally interested, positively or negatively, principally in the process of work. Many factors collaborated to develop this attitude. First of all, the compulsory work under the system of serfdom could hardly awaken any interest in the results. What did the serf care whether his work for the lord was efficient or not? [...] another factor hindered the development of an appreciation of efficiency. The ultimate result of farm-work does not depend exclusively upon the worker himself; his best efforts can be frustrated by unforeseen circumstances, and in a particularly good year even negligent work may be well repaid. 
On a rich background of religious and magical beliefs this incalculable element gives birth to a particular kind of fatalism (Thomas and Znaniecki 1918, pp. 172-173).

This focus on the process and not the result was, in my view, one of the key elements of the peasant mode of work. It enabled people to distance themselves from the influence of uncertain external elements and concentrate on the things that depended on themselves, on their will, skills and wishes. This meant that the local hierarchy could be moulded on the basis of attitudes and work put into the farm, and not the final result achieved. This system was much more objective and fair to farmers, as it was independent of such irrelevant factors as the whims of the market, the decisions of politicians or the weather. ${ }^{4}$ If someone was lazy or took "irrational" decisions, i.e. ones that were unpopular in their particular community (e.g. sowing a sorghum and Sudan grass mix as forage for cattle, at the beginning of the 21 st century in Podlasie, as one of my respondents did, to all of his neighbours' amazement), ${ }^{5}$ they did not win approval even if they managed to obtain quite a high crop and feed their cattle successfully.

Of course, the model in which the rural population functions has always been dynamic, changing throughout the 19th as well as the 20th century. However, I would like to focus on the changes that have occurred within the last 15 years, i.e. more or less since Poland joined the EU, as they seem the most interesting from the point of view of farmers' changing modes of work.

\section{What Has Changed?}

Many of the aforementioned factors have not changed despite the new legal, economic and social circumstances. Farmers still work where they live, they are still dependent on the weather, on epidemics affecting their herds etc. Nevertheless, noticeable changes have taken place in farmers' predominant modes of work over recent decades. Almost 15 years have passed since my first studies on farmers' strategies of work and survival in Podlasie (Krzyworzeka 2014), and it is very clear

${ }^{4}$ Nonetheless, it is worth noting that some results of work have been and still are subject to local judgement, e.g. the amount of weeds or even the height of corn, if this testifies to someone's ability to apply fertilisers correctly. More about the nuances of judging neighbours' work based on its visible effects can be found in papers by Anna Jakubowska (2020), Maria Bolek and Anna Jakubowska (2019). However, such judgements do not depend on unpredictable external influences.

5 He himself was very happy about his decision: he had three harvests in one year and claimed that the sorghum and Sudan grass mix was very good forage for cows. However, most of the local farmers I spoke to thought his idea was weird to say the least, and some even saw it as harmfully risky (cf. Krzyworzeka 2014, p. 200). Over the subsequent several years of my research in the region, no one followed his example. 
how the way that most farmers in the region function has changed. ${ }^{6}$ Many of my respondents from the years 2006-2007 have since retired, and if their farms have been taken over by their children, quite a few changes have been made. The younger ones who still work have adjusted to the changing reality and work differently today. The main difference is in the scale of operations. These are not drastic changes: Podlasie does not offer opportunities to buy 300 ha of land overnight and set up a really large farm; the process moves forward slowly. For example, one year a farmer might start leasing 5 ha from a neighbour who has retired, and the next year - buy 2 ha from a deceased farmer's children uninterested in keeping the land.

A continuation of my research in Podlasie has shown that the deagrarianisation of rural areas in eastern Poland has deviated from the intended model, which included plans to bring other, non-agricultural operations to the countryside (Rosner and Stanny 2018; ${ }^{7}$ Kołodziejczak 2017; Szymańska 2008). For now, people who give up farming either retire or migrate to urban areas or foreign countries. Those who stay on, work on increasingly large farms, but the employment structure does not change: it is still just the farmer, sometimes helped by family members. ${ }^{8}$ As a result, farmers show a growing level of frustration, exhaustion and discouragement.

It might appear to be a paradox that with the decreasing number of farms and simultaneously increasing farm area, the group of former farmer owners thus freed does not automatically move to the hired agricultural worker sector. This was undoubtedly the effect expected by some observers when EU agricultural policy first started being introduced. In this case, however, a much stronger factor than economic stimuli emerged: cultural baggage. Reluctance to work for another farm owner is a very deeply rooted attitude among Polish farmers; to this day, such a person is referred to locally by the derogatory term parobek (farmhand). Ethnographers have actually observed this for a long time. For example, Michał Buchowski wrote that "working for farmers is [...] considered a last resort" (Buchowski 1996, p. 39), while Zadrożyńska noted: "for residents of the Podlasie countryside, for example, working on someone else's land was perceived in terms of humiliation" (Zadrożyńska 1983, p. 75; cf. also Harris 2005, p. 435; Jaworska and Pieniążek 1995, p. 17; Pine 2002, p. 87 et seq.). Being a hired worker on a neighbour's farm is such a sensitive issue that it is not only

6 I would like to underline that the conclusions and observations offered here apply to several regions in Podlaskie province. I would not be prepared to make any generalisations about Polish agriculture as a whole on their basis, as it is too varied for this to make sense. The mechanisms I outline might, of course, apply to many farmers, but a lot would depend on the specific circumstances of a particular farm and region.

7 As Andrzej Rosner and Monika Stanny rightly point out, deagrarianisation is a very old phenomenon; today we are simply witnessing its considerable intensification.

8 For analysis of other countries from the region see: Amersdorffer et al. 2015; Balezentis et al. 2020; Juska, Poviliunas and Pozzuto 2006; Mincyte 2011; Swain 1999; Věžník, Král and Svobodová 2013. 
extremely rare, but also seldom talked about; most of my respondents did not cite this motivation directly, but spoke of other factors that might have influenced their decision (cf. Krzyworzeka 2014, p. 198). In the face of a significant increase in farm area and scale of production, therefore, farm owners cannot rely on finding workers easily. ${ }^{9}$ Nor can they count on neighbourly help, something that used to work well for many decades, if not centuries (Zawistowicz-Adamska 1951, 1976). However, as Richard Wilk points out, wherever the role of paid employment (and also production for sale) increases in agriculture, cooperation networks within the community grow weaker (Wilk 1987, p. 305). There are many reasons for this, including mechanisation, which means that not everyone has the qualifications to help with a given job, but also - in a paradox the enlargement of farms, as this means everyone has more work on their own farm and is unable to help their neighbours. As a result, farmers are thrust into a vicious circle. They expand their farms without a functioning agricultural-worker labour market and in a situation in which few elements of their operations are subject to outsourcing.

In addition, farmers increasingly cannot really count on help from their own family. This is connected with the multifaceted social changes occurring in recent decades: periods when the situation in agriculture was one of uncertainty, operating in the sector was not very profitable, and parents strongly supported their children's aspirations to break free of the countryside, helped them obtain the necessary education and supported their decisions to move to the city. Today as well, even though farming seems quite a good option financially, compared to an uncertain job in the city, many owners of successful farms are preparing for a scenario in which none of their children will take it over in future, and they do not particularly seem to encourage them to do so. That is an enormous change compared to several decades ago, when the upbringing of young people in the countryside virtually consisted in adapting them to their future work in agriculture (Harasimowicz 2019). On the one hand, it was obvious that not all the children ${ }^{10}$ would be able to stay

9 Increasingly often, though still on a small scale, one can find Ukrainians or Belarusians employed illegally as seasonal workers. However, this is not an option used on a mass scale, among other things because it requires providing the workers with lodging, which in the rural reality - given its lack of real estate for rent - means having the workers live with the farmer's family in the family home. For many farmers, that is the deciding argument against this option. In the community I studied, the only exception known to me was the owners of a very large poultry farm, who simply put up a separate residential building for workers from across the eastern border, something the average farmer in the region could not afford.

10 Or, more accurately, all the sons, because a daughter might marry a farmer and stay in the countryside, without depleting the family farm. It was not until recent decades that mothers started strongly discouraging their daughters from remaining in the countryside. Their opinion of the life of a farmer's wife is often very negative, and they want their daughters to be spared such a fate. In a paradox, this leads to another problem, namely a sex imbalance in rural areas as well as the fact that the sons cannot find a life partner (of course, there are other reasons for this as well) (cf. Dąbrowska 2020). 
in the countryside, but on the other, it was equally obvious that one of them would have to, so all of them needed to be taught farming just in case. It was thus natural that children had a lot of duties on the farm from an early age; their work provided measurable help that lightened the parents' burden. Today there are ever fewer children in families and everyone acknowledges the importance of an education, so parents and grandparents do not dare interrupt a child who is learning (or, more precisely, sitting in front of the computer), and as a result, teenage children do not help on the farm at all in many families. Since women increasingly often work outside the farm and the countryside (as teachers, clerks, shop assistants etc.), they do not perform jobs on the farm to the extent they used to either. ${ }^{11}$ Consequently, I have seen a growing number of situations in which a farm that has been significantly expanded over the past dozen or so years is operated almost completely by one person. Of course, this is coupled with growing mechanisation, but this in turn means further necessary investment, and also, though it enables the scale of production to be increased, it does not serve to reduce the overall amount of work.

The situation outlined above not only leads to overwork, frustration and a feeling of meaninglessness, but also has a significant impact on social relations within the rural community. Of course, rural residents have never been a homogeneous group; the differences have been based on different criteria in different periods, whether it was family background, wealth or, in some regions, religious and ethnic issues (cf. Buchowski 1996; Bystroń 1947; Dobrowolski and Woźniak 1976; Cancian 1989; Roseberry 1989; Harris 2005). In the post-transformation period, Michal Buchowski (1996) used the classical language of class differences to describe a certain village in the Wielkopolska region. ${ }^{12} \mathrm{~A}$ slightly different distinction has appeared in Podlasie most recently, only seemingly invoking the category of ownership. This has been interestingly described by Magda Kalinowska (2020), who suggests that the category of the "large-scale farmer" is a new figure for the "Other" in the countryside. This is a potent claim, which the author illustrates with even stronger material from her research, citing recurring opinions about neighbours that include terms like "labour camps" as well as figures of speech denying them humanity (p. 136 et seq.). This new stratification, which began in 2004 and has been gradually building up, ${ }^{13}$ is currently felt very strongly and commented upon by rural

11 Women are often responsible for maintaining the increasingly complicated farm documentation and for contacts with the administration, banks etc., i.e. the part of agricultural operations that has emerged and developed relatively recently.

12 Which might not necessarily be applicable to other villages in Poland (see Krzyworzeka 2014, p. 61).

13 As mentioned earlier, farms were usually expanded slowly, with the purchase or tenancy of a few hectares at a time and gradual investment in machinery, new buildings and fittings. 
residents themselves. Those who have not entered the spiral of farm modernisation and expansion watch their neighbours' actions with incomprehension and horror, thinking they have voluntarily given up their freedom, that they work like carthorses, with the threat of over-investment constantly hanging over their heads in the form of loans that are impossible to pay off. Kalinowska also shows that "large-scale farmers" are often spoken of with compassion, in the belief that they must have come to regret their decisions to expand and step on the path of continuous farm development, but are unable to give it up because it is a one-way street.

Farmers who have invested in enlarging and mechanising their farms are losing control not only over how and how long they work, but also over the effects of their labour. On the example of milk producers from Podlasie, Agnieszka Kosiorowska (2019) shows that today's farmers have been excluded from the process of evaluating the quality of the food they produce. Whereas in the past they were able to judge if the milk "was not sour and was not too warm" (p. 19), i.e. they performed the same process as the person at the milk collection point, today this evaluation is carried out far away from them, in a dairy laboratory, by means of scientific methods and special equipment whose workings they are not familiar with and do not understand, using non-intuitive concepts difficult to translate into their daily activity (bacteria count and somatic cell count). Kosiorowska writes that farmers have lost control over the milk production process despite maintaining ownership of the means of production. The proliferation of legal regulations, norms and rules based on scientific knowledge that is external to the agricultural world, and their introduction as the only worthy criteria of assessing a farmer's work, strips farmers of their agency. They now have to perform their own work on their own farm according to unfamiliar categories that are not necessarily compatible with locally recognised and socially acceptable norms.

On top of that, there is a multitude of non-agricultural duties that complement farming operations: the necessity to keep all kinds of documentation for every animal on the farm and every investment, inspections of different aspects of the farm's operations, applications to be submitted, subsidies to be accounted for; in other words, lots of paperwork. As a result, an issue that Witold Pieniążek and Grażyna Jaworska's respondents complained about in the early 1990s, namely that farmers had to demonstrate non-agricultural skills in trading in order for their work to bring the anticipated effects, is now greatly compounded. A successful farmer not only has to be a good salesperson/businessperson who understands how the market works, predicts price fluctuations etc., but also an efficient bookkeeper, lawyer, clerk and veterinarian. Despite increasing specialisation in purely agricultural work, farmers constantly have to take training courses and upgrade their skills in many areas they never considered when they were deciding to become farmers. Many 
find it overwhelming. Some delegate these tasks to specialists (but this is costly and requires a very high level of trust), or at least to other family members who seem to be better suited to them (e.g. university student children; the paperwork also often falls to farmers' wives). For many, though, this is extra work that they carry out in the evenings or when they are less busy, which leads to frustration and no time left for any activities unrelated to work.

In the olden days, work lasting all day long was nothing unusual for farmers, but - as Zadrożyńska points out - it is worth noting that particular actions "were performed throughout the day with varying intensity" (1983, p. 20), the effect actually being a feeling of constant bustling about (Jaworska and Pieniążek 1995, p. 16), but not a sense of inhuman and pointless work (people's sense of the "obviousness" or "naturalness" of work helped) ${ }^{14}$ In the present-day reality, there is a shortage of non-work time, i.e. those moments that enabled people to uphold relationships through socialising, to rest and have fun, without disturbing the work order. In other words, just a few decades ago, despite bustling around all day long, working without a standardised time for work and also having duties to perform on Sundays and holidays, farmers had non-work time at their disposal (though this was not free time in today's sense of the term), which balanced out those work duties. Current structural changes have led to a situation in which steadily expanding farms are burdening farmers to a much greater extent, not only physically but also mentally, and the ever-shrinking space of non-work has become insufficient to balance out the huge work load. This has happened not only due to pure arithmetic (number of work hours versus number of non-work hours), but also because rural residents - following the example of urban residents - have started using the concept of free time. An hour's breather at breakfast, an afternoon meeting with a neighbour or watching TV are activities that are not treated as a balance for work, because while being non-work, they are not separately distinguished free time either. And free time as they know it from the media and their ideas about life in the city, e.g. a two-week holiday at a resort abroad, is something farmers are unable to afford. Their frustration is compounded by the fact that it is not money which constrains them (most of the farmers described here, with extensive farms, would easily be able to bear such an expense once a year), but the unique character of agricultural operations and the fact that farm expansion has changed the way this work is performed. You can no longer ask a neighbour to watch over a couple of cows for a few days, nor will your city-based brother-in-law be able to lend a hand,

14 This applies to the 20th century. We do not have many good "first-hand" sources to be able to say much about the feelings of serfs, but there is every indication that their work was incomparably harder than the work of farmers in communist Poland (cf. Szpak 2013), and also farmers in the two inter-war decades. 
because there is too much responsibility connected with hygienic and technological requirements, and too much work to cope with, even temporarily, for someone who does not usually work on the farm. ${ }^{15}$

To all appearances, farmers' modes of work have thus not diverged much from the traditional model characterised by constant bustling around, ${ }^{16}$ but the details have changed considerably: the intensity of work, social relations with neighbours, the possibility of getting away from the farm even for just a few days. Loneliness has also appeared, increasingly affecting farmers today. Most importantly, however, the farmers' own assessment has changed: much more than before, today their aspirations are shaped by the urban mode of work and consumerism, familiar to them from personal local experience and from the media. Comparing themselves to the average office worker, who puts in the required eight hours without much stress and then goes home to spend free time on fun pastimes, obviously gives rise to frustration among farmers, and opposition to the mode of work they themselves pursue. What was once essentially a religious obligation towards the land, things sacred and society, has ceased to be the main point of reference; it has been replaced by the modes of work and consumption determined by other members of society.

\section{Conclusion}

As a result of structural changes in rural areas, such as deagrarianisation, the resultant migrations and also the professional emancipation of women, work in agriculture has lost its social character. Instead of connecting people with one another and serving as a pretext for building and maintaining neighbourly and social relations, it has become an isolating element. Most often, farmers no longer work on the farm with other family members (who are busy with other things: their education, a job in the city), nor do they take advantage of help from their neighbours (who either have their own farm keeping them very busy

15 Just a dozen or so years ago, the wife of a local administration member in Podlasie, herself the operator of a sizable dairy farm together with her son, told me about the agreement she had with her husband: she went away with friends to Masuria or the mountains for two weeks twice a year, and her husband stood in for her, helping the son run the farm. However, this arrangement was not seen as ideal, as it did not enable the family members to go away on holiday together.

16 As Zadrożyńska notes, in the present-day mode, tradition "is probably an inspiration for cultural transformations and variants". Despite a fascination with the dynamic changes of recent years, or perhaps precisely because of them, it is worth remembering that "the continuity of our culture is an indisputable fact", and that both in olden times and today, "tradition (or, more precisely: its power of influence) plays a major role as a mechanism of the transfer, continuance and ties between individual components of culture" (1983, pp. 16-17). Earlier models do not simply vanish; they are transformed, they remain in the memory as a point of reference and an element helpful for judging contemporary reality etc. 
or have already retired, or work in the city, so the old system of exchanging work no longer includes them). Consequently, performing a growing number of duties is taking up so much of farmers' time and costing them so much energy that there is no room left for socialising, neighbourly relations, or even family activities. Even necessary professional contacts, e.g. with commune officials, employees of the Agency for Restructuring and Modernisation of Agriculture (ARiMR), people from the dairy or the bank, do not fill this social void, because they are increasingly marked by mutual haste as well as being squeezed into the rather restrictive scripts of contacts between officials and petitioners. On the one hand, this ensures greater professionalism in customer service, but on the other it deprives farmers of yet another opportunity to talk about their problems, share their dilemmas etc. (in earlier times, such contacts abounded in personal elements; these relations often resembled friendship, and every meeting offered an excuse to have a conversation). Loneliness is a new aspect of agricultural work, and we will likely start seeing its effects in the near future.

Today's farmers can make enough profit on their operations to guarantee their families quite a good standard of living. At the same time, though, their work has lost its importance in the eyes of society, both among representatives of other social groups (the farmer occupation's prestige, the role of "those who feed the nation" ascribed to them) and in their immediate environment. A steadily decreasing proportion of rural residents are involved in agriculture, and they consequently stop assigning it a key role. By treating agriculture in rather a bureaucratised way, defining all its aspects down to the smallest detail, even institutions dedicated to agriculture (like the ARiMR) are, in a way, stripping it of references to the sacred sphere, of the religious dimension that lent working in agriculture special meaning in olden times. The fact that farmers no longer have to pass on their knowledge and skills to the next generation, since their children will probably choose a more comfortable life in the city and will not take over the farm, is not just another fact diminishing the importance of what they do for a living. In a sense, (as they accept their children's life choices) it also forces farmers to adopt this way of thinking about agriculture, to agree with the arguments of those who see farming as nothing more than just one of many occupations.

\section{References}

Amersdorffer F., Buchenrieder G., Bokusheva R., Wolz A. (2015). Efficiency in microfinance: financial and social performance of agricultural credit cooperatives in Bulgaria. Journal of the Operational Research Society, 66 (1), 57-65.

Applebaum H. (1992). The Concept of Work: Ancient, Medieval, and Modern. Albany: State University of New York Press. 
Balezentis T., Ribasauskiene E., Morkunas M., Volkov A., Streimikiene D., Toma P. (2020). Young farmers' support under the Common Agricultural Policy and sustainability of rural regions: Evidence from Lithuania. Land Use Policy, 94, 1-9.

Bolek M., Jakubowska A. (2019). Different dimensions of diligence in the contemporary Polish rural areas. The Anthropology of East Europe Review, 1, 25-39.

Buchowski M. (1996). Klasa i kultura w okresie transformacji: Antropologiczne studium przypadku społeczności lokalnej. Berlin: Centre Marc Bloch.

Buchowski M. (2006). Dystynkcja przez pracę w społeczności lokalnej w Wielkopolsce. In: J. Kurczewska (ed.), Oblicza lokalności: Różnorodność miejsc i czasu (pp. 193-217). Warszawa: Wydawnictwo Instytutu Filozofii i Socjologii Polskiej Akademii Nauk.

Bukraba-Rylska I. (2012). Socjologia wsi polskiej. Warszawa: Wydawnictwo Naukowe PWN. Bystroń J.S. (1947). Kultura ludowa. Warszawa: Trzaska, Evert i Michalski.

Cancian F. (1989). Economic behavior in peasant communities. In: S. Plattner (ed.), Economic Anthropology (pp. 127-170). Stanford: Stanford University Press.

Chałasiński J. (1938). Młode pokolenie chłopów: Procesy i zagadnienia kształtowania się warstwy chłopskiej w Polsce, vol. 4. Warszawa: Państwowy Instytut Kultury Wsi.

Dąbrowska J. (2020). „Czym się zajmuje żona? Na ogół strofowaniem mnie”. O podziale obowiązków w rodzinach wiejskich na Podlasiu. In: A. Krzyworzeka (ed.), Praca na wsi: Szkice etnologiczne (pp. 260-299). Warszawa: Oficyna Naukowa.

Dobrowolski K., Woźniak A. (1976). Historyczne podłoże polskiej kultury chłopskiej. In: A. Kutrzeba-Pojnarowa, W. Paprocka, M. Biernacka, B. Kopczyńska-Jaworska (eds.), Etnografia Polski: Przemiany kultury ludowej, vol. 1 (pp. 59-90). Wrocław: Zakład Narodowy im. Ossolińskich.

Halamska M. (2000). Charakterystyka społeczna polskich rolników. In: X. Dolińska, E. Wosik (eds.), Chłop, rolnik, farmer? Przystąienie Polski do Unii Europejskiej - nadzieje i obawy polskiej wsi (pp. 9-33). Warszawa: Instytut Spraw Publicznych Polskiej Akademii Nauk.

Harasimowicz J. (2019). Natural Born Farmer: Rural childhood and farm work in eastern Poland. The Anthropology of East Europe Review, 36 (1), 40-58.

Harris M. (2005). Peasants. In: J.G. Carrier (ed.), Handbook of Economic Anthropology (pp. 423-438). Cheltenham, UK-Northampton, MA: Edward Elgar.

Jakubowska A. (2020). Moralna ekonomia pestycydów. Opowieści o agrochemikaliach na zachodnim Podlasiu. In: A. Krzyworzeka (ed.), Praca na wsi: Szkice etnologiczne (pp. 154-197). Warszawa: Oficyna Naukowa.

Jaworska G., Pieniążek W. (1995). Konteksty ekonomicznego myślenia: Wolny rynek na wsi z punktu widzenia antropologa. Warszawa: Instytut Ekonomiki Rolnictwa i Gospodarki Żywnościowej.

Juska A., Poviliunas A., Pozzuto R. (2006). Resisting marginalisation: The rise of the rural community movement in Lithuania. Sociologia Ruralis, 45 (1-2), 3-21.

Kalinowska M. (2020). Duży jako obcy. Kategoria „dużego” gospodarza w narracjach społeczności rolniczej gminy Sokoły. In: A. Krzyworzeka (ed.), Praca na wsi: Szkice etnologiczne (pp. 112-153). Warszawa: Oficyna Naukowa. 
Kołodziejczak A. (2017). Koncepcja zintegrowanego rozwoju rolnictwa i wsi a wiejskie obszary funkcjonalne. Rozwój regionalny i polityka regionalna, 37, 41-49.

Kosiorowska A. (2019). Questioning bacteria: How farmers in North-Eastern Poland resist forced progress. The Anthropology of East Europe Review, 36 (1), 3-24.

Krzyworzeka A. (2014). Rolnicze strategie pracy i przetrwania: Studium z antropologii ekonomicznej. Warszawa: Wydawnictwa Uniwersytetu Warszawskiego.

Krzyworzeka A. (2017). „Przyjaźnie przysługowe” jako skuteczny model koegzystencji na pograniczu wiejsko-miejskim. Etnografia Polska, 61 (1-2), 65-82.

Krzyworzeka A. (2018). Włamania i kradzieże jako regulator relacji społecznych. Lud, 102, 257-277.

Krzyworzeka A. (2019). Anthropology of work in Poland. The Anthropology of East Europe Review, 36 (1), 93-102.

Mincyte D. (2011). Subsistence and sustainability in post-industrial Europe: The politics of small-scale farming in Europeanising Lithuania. Sociologia Ruralis, 51 (2), 101-118.

Pine F. (2002). Dealing with money: Zlotys, dollars and other currencies in the Polish highlands. In: R. Mandel, C. Humphrey (ed.), Markets and Moralities: Ethnographies of Postsocialism (pp. 75-97), Oxford-New York: Berg.

Roseberry W. (1989). Peasants and the world. In: S. Plattner (ed.), Economic Anthropology (pp. 108-126). Stanford: Stanford University Press.

Rosner A., Stanny M. (2018). Rozważania o pojęciu i procesie dezagraryzacji polskiej wsi. Wieś i Rolnictwo, 2 (179), 281-292.

Swain N. (1999). Agricultural restitution and co-operative transformation in the Czech Republic, Hungary and Slovakia. Europe-Asia Studies, 57 (7), 1199-1219.

Szpak E. (2013). Mentalność ludności wiejskiej w PRL: Studium zmian. Warszawa: Wydawnictwo Naukowe Scholar.

Szymańska A. (2008). Dezagraryzacja wsi i jej skutki. Rolniczy Magazyn Elektroniczny, Available on: https://cbr.gov.pl/rme-archiwum/2008/rme27/dane/4_4.html [access: 28th September 2020].

Thomas W.I., Znaniecki F. (1918). The Polish Peasant in Europe and America: Monograph of an Immigrant Group, vol. 1. Boston: The Gorham Press.

Věžník A., Král M., Svobodová H. (2013). Agriculture of the Czech Republic in the 21st century: From productivism to post-productivism. Quaestiones Geographicae, 32 (4), 7-14.

Wilk R. (1987). House, home, and consumer decision making in two cultures. Advances in Consumer Research, 14, 303-307.

Wilk R.W., Cliggett L.C. (2009). Economies and Cultures: Foundations of Economic Anthropology. New York: Avalon Publishing.

Wolf E.R. (1957). Closed corporate peasant communities in Mesoamerica and Central Java. Southwestern Journal of Anthropology, 13 (1), 1-18.

Zadrożyńska A. (1983). Homo faber i homo ludens: Etnologiczny szkic o pracy w kulturach tradycyjnej i współczesnej. Warszawa: Państwowe Wydawnictwo Naukowe.

Zawistowicz-Adamska K. (1951). Pomoc wzajemna i współdziałanie w kulturach ludowych. Łódź-Lublin: Polskie Towarzystwo Ludoznawcze. 
Zawistowicz-Adamska K. (1976). Więź społeczna w różnych układach gospodarczo-społecznych polskiej wsi. In: A. Kutrzeba-Pojnarowa, W. Paprocka, M. Biernacka, B. Kopczyńska-Jaworska (eds.), Etnografia Polski: Przemiany kultury ludowej, vol. 1 (pp. 503-520). Wrocław: Zakład Narodowy im. Ossolińskich.

\section{Zmiany rolniczego modelu pracy}

Streszczenie: Na wsi przez długi czas wytwarzał się specyficzny chłopski model pracy, opisywany dość szczegółowo m.in. przez etnografów, historyków czy socjologów wsi. Charakteryzował się on takimi aspektami, jak: skupienie na procesie, a nie efekcie, afirmacja pracy jako takiej, współpraca z członkami rodziny i sąsiadami, zanurzenie pracy w kontekście społecznym. Model ten podlegał znacznym zmianom już w Polsce Ludowej, a ostatnie dekady tylko przyspieszyły ten proces. W obliczu przekształceń strukturalnych wsi, ale też szerszych zmian dotyczących sfery pracy w późnej nowoczesności, wartości dawniej podstawowe dla chłopów przestały odgrywać już tak istotną rolę w życiu współczesnych rolników. Ich miejsce zajęło inne nastawienie, inne umiejętności stały się konieczne, inne postawy zaczęły być cenne, m.in. dlatego że rolnicy są świadomi, iż ich dzieci prawdopodobnie będą musiały odnaleźć swoją ścieżkę zawodową poza rolnictwem i z myślą o tym inaczej je wychowują. W prezentowanym artykule ukazano nie tylko nowe modele pracy rolniczej i związany z nimi system wartości, lecz także źródła, z których rolnicy czerpią takie wzorce.

Słowa kluczowe: etnografia, rolniczy model pracy, praca rolnicza, dezagraryzacja, Polska. 
